\title{
PROBLEMATIKA PENCAPAIAN KOMPETENSI KETERAMPILAN BERBICARA SISWADALAM PEMBELAJARAN BAHASA INDONESIA
}

\author{
Siti Nur Afifatul Hikmah \\ IAI Darussalam BlokagungBanyuwangi \\ afifahikmah16@gmail.com
}

\begin{abstract}
Abstrak
Pembelajaran keterampilan berbahasa di sekolah tidak hanya menekankan pada teori, tetapi siswa dituntut untuk mampu menggunakan bahasa sebagaimana fungsinya. Keterampilan berbahasa menyimak, menulis, membaca, dan berbicara menjadi satu komponen yang tidak terlepas dari aktifitas berbahasa. Kemampuan berbicara juga harus mampu menelaah dan memastikan bahwa apa yang disampaikan dapat diterima dengan tepat oleh pendengar. Faktanya masih terdapat pelbagai hambatan dalam berbicara baik faktor internal maupun faktor eksternal.Evaluasi pembelajaran berbicara masih berpedoman pada teori berbicara, bukan menekankan pada praktek berbicara.
\end{abstract}

Kata kunci:problematika, kompetensi, dan keterampilan berbicara.

\begin{abstract}
Learning language skills in schools does not only emphasize theory, but students are required to be able to use language as its function. Language skills in listening, writing, reading, and speaking are a component that cannot be separated from language activities. The ability to speak must also be able to analyze and ensure that what is said can be received appropriately by the listener. In fact, there are still various obstacles in speaking, both internal and external factors. Evaluation of learning to speak is still guided by speaking theory, not emphasizing speaking practice.
\end{abstract}

Keywords: problems, competence, and speaking skills.

\section{A. Pendahuluan}

Pendidikan tidak terlepas oleh pembelajaran. Dalam pembelajaran bahasa Indonesia siswa dituntut mampu menguasai empat aspek keterampilan berbahasa, yaitu menyimak atau mendengarkan, berbicara, membaca, dan menulis. Siswa harus menguasai keempat aspek tersebut agar terampil berbahasa. Dengan demikian, 
pembelajaran keterampilan berbahasa di sekolah tidak hanya menekankan pada teori, tetapi siswa dituntut untuk mampu menggunakan bahasa sebagaimana fungsinya, yaitu sebagai alat untuk berkomunikasi. Orang mengkaji bahasa dari segi keilmuannya atau yang berkaitan dengan teori-teori bahasa, sementara sebagian yang lain mendalami hal-hal yang berkaitan dengan segi-segi praktisi dari bahasa.

Pembelajaran berbicara merupakan suatu proses yang melibatkan tiga komponen, yaitu perencanaan, pelaksanaan, dan evaluasi. Ketiga komponen tersebut berinteraksi dalam suatu sistem.Pada intinya hakikat pembelajaran berbicara adalah suatu kombinasi yang tersusun meliputi unsur manusiawi, material, fasilitas, perlengkapan, dan prosedur yang saling memengaruhi sehingga siswa mampu menyampaikan gagasan secara lisan atau kemampuan mengucapkan bunyi-bunyi artikulasi atau kata-kata untuk mengekspresikan, menyatakan, serta menyampaikan pikiran, gagasan, dan perasaan yang dapat dipadukan dengan aspek pengetahuan (kosakata, frase, kalimat) atau dengan pemahaman (menyimak dan membaca) sehingga tujuan pembelajaranakan tercapai.

Pembelajaran akan tercapai secara maksimal dengan sarana dan prasarana pembelajaran yang memadai. pembelajaran yang baik mampu merumuskan tujuan dan pencapian kompetensi. Mulyasa (2013: 136) memaparkan bahwa perencanaan menyangkut perumusan tujuan dan kompetensi serta memperkirakan cara pencapaian tujuan dan pembentukan kompetensi. Untuk mencapai tujuan pembelajaran yang diinginkan guru harus bisa melakukan tiga komponen tersebut yaitu perencanaan pembelajaran, pelaksanaan pembelajaran, serta evaluasi pembelajaran. Hal ini sejalan dengan (Sanjaya 2011: 103) yang menyatakan bahwa pembelajaran perlu memberdayakan semua potensi siswa untuk menguasai kompetensi yang diharapkan.Berbicara merupakan salah satu keterampilan berbahasa dan menunjang ilmu-ilmu lainnya.

Berbicara merupakan keterampilan berbahasa yang membutuhkan rasa percaya diri peserta diri untuk mengungkapkan setiap gagasan melalui lisan. Selama ini berbicara belum sampai pada ranah yang diinginkan oleh guru dalam mencapai kompetensi. Menurut Wardhani, dkk. (2016:) bahwa keterampilan berbicara selama ini belum mendapat porsi perhatian yang lebih dari guru, sebagaimana keterampilan berbahasa yang lain (menyimak, membaca, dan menulis). Guru harus mampu 
mengarahkan semua potensi siswa dengan baik, tidak hanya menyampaikan materi, tetapi siswa harus mampu menguasai materi yang disampaikan oleh guru. Salah satu kemampuan berbahasa yang sangat perlu dikuasai seseorang adalah kemampuan berbicara.. Kemampuan berbicara tidak didapat begitu saja oleh siswa, sebagian besar memerlukan latihan atau pengalaman berbicara.

Kemampuan berbicara seseorang tentu tidak sekedar mampu mengemukakan apa yang ingin disampaikannya kepada pendengar atau lawan bicaranya. Kemampuan berbicarajuga harus mampu menelaah dan memastikan bahwa apa yang disampaikanya itu dapat diterima dengan tepat oleh pendengar (Lailiyah dan Wulandari, 2016:168). Dengan demikian, seseorang dapat berbicara secara efektif atau tepat sasaran dan tercapai apa yang diinginkanya.Keterampilan berbicara yang diajarkan oleh guru kepada siswa yang dituntut aktif dalam menyampaikan gagasan ide. Fakta yang dijumpai dilapangan siswa kurang aktif dan cenderung pasif. Perlu adanya penggunaaan strategi pembelajaran yang menyenangkan dan dapat menstimulus siswa. Sampai detik ini keterampilan berbicara belum bisasepenuhnya mengubah siswa berani menyampaikan gagasan, ide pikiran dan lancar berkomunikasi. Dalam berbicara siswa dituntut untuk mampu mengungkapkan pikiran dan gagasannya.

Evaluasi keterampilan berbicara sebaiknya diarahkan untuk mengetahui keterampilan berbicara siswa. Hal ini sejalan dengan pendekatan komunikatif yang digunakan dalam pembelajaran. Realisasinya adalah evaluasi dilakukan dengan cara menugasi siswa berbicara dan dievaluasi sesuai dengan indikator-indikator keterampilan berbicara yang telah ditentukan. Walaupun demikian, evaluasi keterampilan berbicara juga bisa diarahkan untuk mengevaluasi pengetahuan dan pemahaman siswa tentang hal-hal yang berkaitan dengan keterampilan berbicara.

Evaluasi dalam pembelajaran berbicara dalam bentuk praktek berbicara. Praktek langsung berbicara akan membuat siswa mampu berbicara. Tujuan dalam pembelajaran berbicara yaitu agar siswa mampu berbicara, jadi evaluasi dalam pembelajaran berbicara dilakukan dengan praktek langsung berbicara. Dalam hal ini, bukan berarti benar-benar terlepas dari teori berbicara. Evaluasi pembelajaran berbicara masih berpedoman pada teori berbicara, bukan menekankan pada praktek berbicara. 
Hambatan yang dihadapi oleh siswa dalam berbicara berasal dari faktor internal maupun eksternal. Rusmiati (2002: 32) mengemukakan bahwa hambatan tersebut terdiri atas hambatan yang datangnya dari pembicara sendiri (internal) dan hambatan yang datang dari luar pembicara (eksternal). Hambatan internal adalah hambatan yang muncul dari dalam diri pembicara. Melihat adanya problematika tersebut diperlukan penelitian ini. Penelitian ini dimaksudkan untuk mengetahui problematika apa sajakah yang dihadapi guru dan siswa dalam pembelajaran berbicara. Jika problematika tersebut sudah diketahui, setidaknya bisa dilakukan perbaikan.

\section{B. Metode Penelitian}

Penelitian ini menggunakan rancangan penelitian deskriptif kualitatif. Rancangan deskriptif kualitatif digunakan untuk memperoleh gambaran yang jelas, objektif, sistematis, dan cermat mengenai fakta-fakta aktual dari sifat populasi.Penelitian deskriptif kualitatif adalah prosedur penelitian yang menghasilkan data deskripsi berupa kata-kata tertulis dan lisan dari orang-orang dan perilaku yang dapat diamati. Menurut Hadari Nawawi (2007:67) mengatakan bahwa metode deskriptif dapat diartikan sebagai prosedur pemecahan masalah yang diselidiki dengan menggambarkan/melukiskan keadaan subyek/obyek penelitian seseorang, lembaga, dan masyarakat pada saat sekarang berdasarkan fakta-fakta yang tampak.Rancangan penelitian deskriptif ini dipilih karena rancangan penelitian ini mampu menggambarkan secara keseluruhan mengenai problematika siswa dalam keterampilan berbicara pada pelajaran bahasa Indonesia.

Subjek penelitian dalam penelitian ini siswa kelas XI SMKN 3 Malang.Sementara itu, objek penelitian adalah problematika dalam pembelajaran berbicara. Sejalan dengan rumusan masalah, objek penelitian secara khusus adalah mengenai problematika keterampilan berbicara. Metode pengumpulan data yang digunakan dalam penelitian ini, yaitu observasi, wawancara, dan studi dokumentasi.Sugiyono (2014:92) menyatakan bahwa Instrumen penelitian adalah suatu alat pengumpul data yang digunakan untuk mengukur fenomena alam maupun sosial yang diamati.Metode analisis data yang digunakan dalam penelitian ini 
adalah mengacu pada konsep Milles dan Huberman, yaitu reduksi data, penyajian data, dan simpulan akhir atas temuan.

Metode pengumpulan data dengan observasi yakni instrumen penelitian yang digunakan adalah lembar observasi. Pada saat melaksanakan observasi, hasil observasi dicatat dalam lembar observasi tersebut. Selain itu, sebagai pendukung pengumpulan data pada observasi juga digunakan alat perekam yang berupa kamera digital untuk merekam pembelajaran berbicara di SMKN 3 Malang.

Metode wawancara yang peneliti gunakan dalam penelitian ini adalah wawancara tidak terstruktur. Metode ini digunakan untuk memperoleh informasi atau data yang lebih akurat mengenai problematika dalam pembelajaran berbicara. Data yang tidak diperoleh melalui observasi dan studi dokumentasi dapat diperoleh lebih lengkap melalui wawancara. Wawancara yang dilakukan yaitu ditujukan pada guru dan siswa. Melalui wawancara oleh guru dan siswa diajukan pertanyaanpertanyaan yang berkaitan dengan problematika dalam pembelajaran berbicara.

\section{Hasil dan Pembahasan}

Data yang diperoleh selama penelitian, berupa hasil observasi, studi dokumentasi, dan wawancara dengan responden yang meliputi tanggapan atau respon siswa mengenai (1) keterampilan berbicara siswapada pembelajaran bahasa Indonesia dan (2) faktor yang mempengaruhi keterampilan berbicara siswa. Datadata yangdiperoleh kemudian dianalisis untuk mengetahui keterampilan berbicara yang dimiliki oleh siswa dan faktor yang mempengaruhi keterampilan berbicara siswa.Menurut Nurgiyantoro (2001:278) bentuk-bentuk kemampuan berbicara yang dipilih harus memungkinkan siswa untuk tidak saja mengucapkan kemampuan berbahasanya, melainkan juga mengungkapkan gagasan, pikiran, atau perasaannya. Pengajaran keterampilan berbicara disesuaikan dengan tingkat penguasaan berbahasa siswa.

Pengajaran dan pembelajaran tidak lepas dari kompetensi dasar. Kompetensi dasar yang akan mengarahkan siswa untuk mempelajari keterampilan berbahasa. Kompetensi dasar adalah satu hal yang sudah diterapkan oleh pemerintah. Dalam silabus kompetensi dasar dibuat untuk menyesuaikan apa yang 
dibutuhkan peserta didik dalam hal pembelajaran. Kemampuan siswa dalam drama dapat diimplikasikan pada materi KD 4.18 mempertunjukkan salah satu tokoh dalam drama yang dibaca atau ditonton secara lisan dan KD 4.19 Mendemonstrasikan sebuah naskah drama dengan memerhatikan isi dan kebahasaan.

Tujuan pembelajaran penting dibuat agar hasil dari sebuah pembelajaran terlihat. Itulah sebabnya tujuan pembelajaran dirumuskan berdasarkan KD dan indikator yang ingin dicapai. Tujuan pembelajaran tersebut dibuat dengan menggunakan kata kerja operasional yang dapat diamati dan diukur, yang mencakup sikap, pengetahuan, dan keterampilan (Putri, dkk. 2017:9).

Media pembelajaran berupa alat bantu proses pembelajaran untuk menyampaikan materi pembelajaran. Media pembelajaran akan mempermudah guru menyampaikan materi pembelajaran dan juga mempermudah siswa untuk memahami apa yang disampaikan oleh guru. Pemilihan media pembelajaran harus disesuaikan dengan materi dan tujuan pembelajaran. Hal ini dimaksudkan agar pembelajaran berjalan secara efektif dan efisien. Pada pembelajaran mengenai pengertian, tujuan dan persiapan-persiapan ketika bermain drama.

Penelitian ini ditujukan kepada siswa kelas XI Jurusan Teknik Komputer Jaringan (TKJ) dan Akomodasi Perhotelan di SMK Negeri 3 Malang, sebagai berikut.Keterampilan Berbicara siswa kelas XI Jurusan Teknik Komputer Jaringan dan Akomodasi Perhotelan.Aspek keterampilan berbicara siswa yang diteliti meliputi ketepatan ucapan, ketepatan intonasi, diksi, sikap, pandangan, gerak-gerik, penguasaan topik, dan kelancaran dalam berbicara. Berikut ini deskripsi hasil observasi, studi dokumentasi, dan wawancara tentang keterampilan berbicara siswa, yakni (1) ketepatan ucapan, (2) ketepatan intonasi, (3) diksi, (4) sikap, (5) pandangan, (6) ketegangan, (7) gerak-gerik, dan (8) kelancaran.

Pertama, ketepatan ucapan. Ketepatan ucapan berdasarkan penelitian yang dilakukan menunjukkan bahwa sebagian siswa masih sering salah dalam mengucapkan suatu kata pada saat berbicara, serta siswa kurang terampil dalam menyusun kalimat yang efektif. Hal ini dilihat dari banyaknya siswa yang mengilangkan huruf konsonan pada saat berbicara. Penelitian yang dilakukan menunjukkan bahwa sebagian siswa masih sering salah dalam mengucapkan suatu 
kata pada saat berbicara, siswa kurang terampil dalam menyusun kalimat yang efektif, siswa yang menghilangkan huruf konsonan pada saat berbicara, baik saat berbicara di depan kelas atau berbicara dengan teman-temannya.

Kedua, ketepatan intonasi. Ketepatan intonasiberdasarkan penelitian yang dilakukan menunjukkan bahwa sebagian siswa kurang terampil dalam menempatkan intonasi, tekanan, nada, dan jeda pada saat berbicara. Siswa belum terlalu mengerti dalam menempatkan intonasi, tekanan, nada, dan jeda dalam berbicara. Hal ini dilihat dari hasil observasi yang menunjukkan bahwa siswa tidak memperhatikan intonasi, tekanan, nada, dan jeda pada saat berbicara. Tujuan utama siswa ketika berbicara di depan kelas adalah dapat dengan cepat menyelesaikanpembicaraannya. Hal ini berakibat pada intonasi, tekanan, nada, dan jeda yang sering diabaikan siswa.

Ketiga, diksi. Diksi yang digunakan siswa berdasarkan penelitian yang dilakukan menunjukkan bahwa sebagian siswa kurang terampil dalam memilih kata yang tepat, konkret pada saat berbicara, bahasa yang digunakan bervariasi dan perbendaharaan kata yang dimiliki siswa kurang. Hal tersebut terlihat ketika siswa kurang menguasai penggunaan ragam bahasa Indonesia saat berbicara. Siswa sering merasa kehabisan kata-kata dalam menyampaikan pembicaraannya. Bahkan, penggunaan kosa kata bahasa daerah kerap ditemui pada tuturan siswa karena siswa merasa kesulitan dalam mencari padanan bahasa Indonesianya. Sebagian besar siswamenggunakan bahasa daerah baik itu di lingkungan sekolah atau dilingkungan masyarakat.

Keempat, sikap. Berdasarkan penelitian ini sebagain siswa sering merasa tidak tenang dan kaku pada saat berbicara. Siswa merasa kaku saat berbicara dikarenakan kurang percaya diri dan terbiasa berbicara di depan umum.

Kelima, pandangan. Pandangan siswa berdasarkan penelitian ini menunjukkan bahwa sebagian siswa sering tidak memperhatikan lawan bicaranya dan pandangan siswa hanya mengarah kepada seseorang saja. Sikap siswa tersebut menunjukkan bahwa siswa tidak siap atau belum siap terhadap lawan bicaranya.

Keenam, gerak-gerik. Gerak-gerik yang dilakukan siswa saat berbicara sering tidak memperhatikan mimik. Mimik dan gerak-gerik yang dilakukan siswa akan mengganggu keefektifan dalam berbicara. 
Ketujuh, penguasaan topik. Penguasaan topik yang dilakukan oleh siswa menunjukkan sebagian siswa kadang mengalami masalah menguasai topik yang akan disampaikan. Penguasaan topik terlihat saat siswa presentasi terkadang kurang mampu menjawab pertanyaan yang diberikan oleh teman-temannya dan bahkan jawaban siswa menyimpang.

Kedelapan, kelancaran. Kelancaran berbicara berdasarkan penelitian yang dilakukan menunjukkan bahwa pada saat berbicara sebagian siswa sering terbatabata, menyelipkan bunyi “ee, aa, em, apa itu”, dan siswa sering mengulang kata yang sama. Bahkan siswa kurang percaya diri atau enggan ketika diminta maju ke depan kelas untuk berbicara. Hal ini dikarenakan siswa merasa takut apabila salah mengucapkan kata dan ditertawakan oleh teman-temannya.

\section{Kesimpulan}

Pembelajaran bahasa Indonesia siswa dituntut mampu menguasai empat aspek keterampilan berbahasa, yaitu menyimak atau mendengarkan, berbicara, membaca, dan menulis.Berbicara merupakan keterampilan berbahasa yang membutuhkan rasa percaya diri peserta diri untuk mengungkapkan setiap gagasan melalui lisan. Salah satu kemampuan berbahasa yang sangat perlu dikuasai seseorang adalah kemampuan berbicara.Keterampilan berbicara yang diajarkan oleh guru kepada siswa yang dituntut aktif dalam menyampaikan gagasan ide. Fakta yang dijumpai di lapangan siswa kurang aktif dan cenderung pasif.Hambatan yang dialami siswa dari faktor internal maupun faktor eksternal. Penelitian ini menggunakan pendekatan deskriptif kualitatif. Metode yang digunakan, yaitu observasi, studi dokumentasi, dan wawancara.

\section{Daftar Pustaka}

Ades, S. 2011. Model-Model Pembelajaran. Jakarta: Bumi Aksara

Jurnal Kata (Bahasa, Sastra, dan Pembelajarannya) November 2017

Lailiyah, N. \& Wulansari, W. 2016. Peningkatan Keterampilan Berbicara Melalui

Metode Diskusi Kelompok Model Tanam Paksa Siswa Kelas X

Pemasaran 1 SMK Pgri 2 Kediri. JURNAL PENDIDIKAN Volume 1

Nomor 2 Tahun 2016. 
Mulyasa. 2013. Pengembangan dan Implementasi Kurikulum 2013. Bandung: PT Remaja Rosdakarya.

Nurgiyantoro, B. 2001. Penilaian dalam Pengajaran Bahasa dan Sastra. Yogyakarta: BPFE.

Putri, H. N., Ling, S., \& Samhati, S. 2017. Kemampuan Berpidato Siswa Kelas X SMA Negeri 3 Kotabumi dan Implikasinya.Jurnal Kata (Bahasa, Sastra, dan Pembelajarannya). November 2017

Wardhani, Sumarwati, \& Purwadi. 2016. Upaya Meningkatkan Keterampilan Berbicara Melalui Pembelajaran Berbasis Masalah Pada Siswa Sekolah Dasar: Penelitian Tindakan Kelas.BASASTRA Jurnal Penelitian Bahasa, Sastra Indonesia dan Pengajarannya, Volume 4 Nomor 2, Oktober 2016. 